Jurnal REKSA: Rekayasa Keuangan, Syariah, dan Audit

p-ISSN: 2089-6581 | e-ISSN: 2614-3720

JURNAL REKSA

Vol.07, No. 02, 2020, PP. 133-150

Vol. 07, No. 02, 2020, pp. 133-150

\title{
DETERMINAN PENGUNGKAPAN MODAL INTELEKTUAL PADA PERUSAHAAN PERBANKAN
}

\section{Zamrud Mirah Delima}

Fakultas Ekonomi dan Bisnis Universitas Muria Kudus

Email: mirah.delima@umk.ac.id

Zuliyati

Fakultas Ekonomi dan Bisnis Universitas Muria Kudus

Email: zuliyati@umk.ac.id

\begin{abstract}
The purposed of this research is to analyze the factors which influence of intellectual capital disclosure. Knowledge of intellectual capital disclosure in the digital era was the important contributing factor to increase performance, professionalism, and sustainable of value excellence for banking companies in Indonesia for performance more optimally. The factors that tested in this research were leverage, earning growth, company size, board of commissioner size, company age, and business complexity toward intellectual capital disclosure. The method of data collecting in this research was taken banking companies which registered at Indonesia Stock Exchange in period 2013 until 2019 as the object. The sampling that used in this research was purposive sampling technique and gained the data of 175 companies which registered at Indonesia Stock Exchange in period 2013 until 2019. The method of analyze that used was multiple regression analysis. The result of the hypothesis testing in this research showed that leverage, company size, board of commissioner size, business complexity had significant influence, where as earning growth and company age were not effect toward intellectual capital disclosure.
\end{abstract}

Keywords : Intellectual Capital Disclosure, Leverage, Earning Growth, Company Size, Board of Commissioner Size.

\section{PENDAHULUAN}

\section{Latar Belakang}

Penyajian informasi merupakan salah satu cara dalam menyampaikan pemenuhan pertanggungjawaban perusahaan terhadap pemegang kepentingan. Transparansi informasi keuangan maupun non keuangan menjadi salah satu aspek penting dalam mengetahui tata pelaksanaan dan kinerja sebuah perusahaan. Informasi keuangan terdiri dari laporan posisi keuangan, laporan laba rugi, laporan perubahan modal, laporan arus kas, dan laporan catatan atas laporan keuangan. Sedangkan informasi non keuangan terdiri dari segala hal yang mendukung aktivitas perusahaan salah satu diantaranya adalah kinerja sumber daya manusia, konsumen atau nasabah, hak paten dan merek, pengetahuan serta teknologi yang merupakan bagian dari modal intelektual biasanya dijabarkan di dalam sebuah annual report perusahaan yang sulit dikuantifikasikan. 
Zamrud Mirah Delima, Zuliyati | Determinan Pengungkapan Modal Intelektual ...

Pengungkapan informasi keuangan dan non keuangan di Indonesia didukung oleh regulasi Bapepam Kep-134/BL/2006 yang menyatakan bahwa kewajiban bagi perusahaan publik untuk menyampaikan laporan tahunan. Selain itu terdapat PSAK No. 19 (revisi 2009) yang meregulasikan tentang aset tidak berwujud. Namun, informasi mengenai item modal intelektual tidak ikut diatur dalam regulasi tersebut. Pengungkapan item modal intelektual dapat dilakukan dengan melalui pengungkapan modal intelektual yang didukung oleh IAS 38 (di Indonesia PSAK 19), bahwa aset tidak berwujud tidak secara eksplisit menyatakan entitas dapat merubah klasifikasi aset tidak berwujud dari memiliki masa manfaat terbatas menjadi tidak terbatas (PSAK 19 revisi 2009).

Perkembangan teknologi dan informasi pada era saat ini memicu terjadinya perubahan gaya hidup serta cara seseorang dalam berbelanja. Hal semacam ini memunculkan adanya transformasi industri di perusahaan-perusahaan terutama yang bergerak dalam sektor perbankan. Transformasi industri di perusahaan perbankan terletak pada sistem pelayanan perbankan yang serba digital sehingga mengakibatkan perubahan pengungkapan modal intelektual pada setiap perusahaan perbankan tersebut. Petty dan Guthrie (2000) menyatakan bahwa "intellectual capital is instrumental in the determination of enterprise value and national economic performance" serta merupakan kunci dan sumber potensial kompetitif yang berkelanjutan (Tayles et al, 2002; Hayton, 2005).

Knowledge pengungkapan modal intelektual pada sektor perusahaan perbankan di Indonesia masihlah sangat terbatas dan bersifat sukarela. Perusahaan dapat memutuskan jenis dan jumlah informasi modal intelektual yang akan dipublikasikan (Ho et al, 2012). Hal tersebut memperjelas bahwa pengungkapan modal intelektual masih bersifat sukarela. Menurut Subramanyam dan John (2010) menerangkan bahwa pengungkapan modal intelektual secara sukarela oleh manajer merupakan sumber informasi yang semakin penting. Dikarenakan peran manajer dapat memberikan arahan yang baik kepada para stakeholder bahwa perusahaan tersebut telah mencapai kinerja yang baik dan optimal. Sehingga terdapat nilai urgensi pengungkapan modal intelektual pada perusahaan perbankan di Indonesia. Dikarenakan informasi pengungkapan modal intelektual yang disajikan pada laporan tahunan perusahaan dapat menarik minat investor dalam menilai kinerja perusahaan tersebut dan menjadi karakteristik keunggulan tersendiri bagi nilai perusahaan untuk terus bersaing serta semakin berkembang di era modern ini.

Peran startegis dari pengungkapan modal intelektual adalah sebagai sebuah keunggulan tersendiri dalam menghadapi kompetisi bisnis yang tidak dimiliki perusahaan lainnya (pesaing). Dikarenakan pengungkapan modal intelektual pada laporan keuangan tahunan disetiap perusahaan memiliki ciri khas tersendiri yang sulit ditiru oleh perusahaan lain. Bagi investor, segala macam pengungkapan yang dilakukan perusahaan adalah salah satu cara untuk melindungi pihak investor dengan diterapkannya corporate governance (tata kelola) dari pasar yang tidak efesien (Arifah, 2012). Tujuan dari penelitian ini adalah untuk menguji faktor-faktor yang mempengaruhi pengungkapan modal intelektual perusahaan perbankan yang terdaftar di Bursa Efek Indonesia dengan faktor-faktor tingkat utang, pertumbuhan laba, ukuran perusahaan, ukuran dewan komisaris, umur perusahaan dan kompleksitas bisnis.

Jurnal REKSA: Rekayasa Keuangan, Syariah, dan Audit, Vol. 07, No. 02, 2020, pp 133-150 | 134 
Zamrud Mirah Delima, Zuliyati | Determinan Pengungkapan Modal Intelektual ...

\section{TINJAUAN PUSTAKA}

\section{Teori Agensi}

Teori yang mendasari penelitian ini adalah teori agensi. Teori agensi merupakan penggambaran hubungan keagenan atau kontrak kerja antara pihak agen dan pihak prinsipal. Pihak prinsipal bertindak sebagai pemilik modal yang memiliki akses informasi internal perusahaan, sedangkan agen adalah pelaku praktek operasional perusahaan memiliki informasi tentang operasi dan kinerja perusahaan secara nyata serta menyeluruh. Sehingga hubungan keagenan muncul ketika satu atau lebih individu menggaji individu lainnya (pihak agen) untuk bertindak atas namanya dan mendelegasikan kekuasaan untuk mengambil sebuah keputusan kepada pihak agen (Atmaja, 2008:12).

Teori agensi menganggap pendelegasian otoritas pengambilan keputusan memungkinkan pihak manajemen yang bertindak sebagai agen dapat melakukan tindakan penyalahgunaan sumber daya perusahaan demi kepentingan pribadi. Hal ini mengakibatkan timbulnya konflik antara pihak manajemen sebagai pengendali dan pemegang saham sebagai pemilik perusahaan (Cahya, 2013).

\section{Definisi Modal Intelektual}

Para ahli masih memperdebatkan mengenai definisi modal intelektual di dalam literatur mereka. Namun, laporan keuangan digunakan untuk tujuan umum (general purpose annual reporting) sebagai dasar dapat dikatakan bahwa tingkat pengungkapan modal intelektual dapat dipandang sebagai suatu laporan yang dimasukkan untuk memenuhi kebutuhan informasi bagi pengguna, dimana hal ini dipersiapkan untuk pelaporan sehingga dapat memenuhi seluruh kebutuhan mereka (Abeysekera, 2005).

Untuk memenuhi kebutuhan pengungkapan modal intelektual pada sebuah perusahaan maka diperlukan pemahaman terkait definisi modal intelektual dengan melalui asset intangible agar perusahaan dapat menyusun dan menerapkan strategi serta kebijakan-kebijakan lain guna mengambil sebuah keputusan dalam menjalankan kegiatan evaluasi dan memaksimalkan kinerja perusahaan. Ide atau gagasan mengenai modal intelektual dimulai pada pertengahan tahun 1980-an yang di indikasikan dengan munculnya pergeseran dari production based to service ke knowledge-based economy (Anatan, 2006).

\subsection{Komponen modal intelektual}

Modal intelektual dapat diklasifikasikan kedalam beberapa komponen bagi perusahaan yang terbagi menjadi Human Capital, Structural Capital, atau Organizational Capital, dan Relational Capital (Cahya, 2013). Human Capital adalah lifeblood dalam modal intelektual, dimana terdapat sumber innovation dan improvement tetapi juga merupakan komponene yang sulit untuk diukur. Human Caiptal menggambarkan tentang kemampuan kolektif suatu perusahaan dalam menghasilkan solusi terbaik berdasarkan pengetahuan yang dimiliki masing-masing individu di dalam perusahaan tersebut.

Srtuctural Capital adalah kemampuan perusahaan dalam memenuhi proses rutinitas perusahaan dan strukturnya yang mendukung usaha karyawan agar menghasilkan

Jurnal REKSA: Rekayasa Keuangan, Syariah, dan Audit, Vol. 07, No. 02, 2020, pp 133-150 | 135 
Zamrud Mirah Delima, Zuliyati | Determinan Pengungkapan Modal Intelektual ...

kinerja intelektual yang optimal baik kinerja bisnis secara menyeluruh, seperti halnya sistem operasional perusahaan, proses manufakturing, budaya organisasi, filosofi manajemen serta seluruh bentuk intellectual property yang dimiliki setiap perusahaan. Relational Capital adalah komponen modal intelektual yang memberikan nilai secara riil yang merupakan hubungan harmonis perusahaan dengan para mitranya baik dari para pemasok yang andal dan berkualitas.

\subsection{Pengungkapan informasi modal intelektual}

Pengungkapan modal intelektual tidak disajikan di dalam laporan posisi keuangan, dikarenakan pengungkapan modal intelektual silit untuk diukur dan dikuantifikasikan. Sehingga belum ada standar resmi yang mengatur tentang pengungkapan modal intelektual maka sulit untuk mengidentifikasi item-item apa saja yang merupakan komponen modal intelektual (Priyanti, 2015). Menurut Fitriani (2012), kerangka kinerja akuntansi dan standar akuntansi yang berlaku kurang memungkinkan untuk melakukan pengakuan serta pengungkapan penuh pada komponen modal intelektual. Sehingga, metode pengukuran baru dan pengungkapan modal intelektual seperti indeks modal mampu membantu mengatasi permasalahan standar akuntansi keuangan tradisional di dalam pengukuran modal intelektual.

Pengukuran modal inteletual dalam penelitian ini menggunakan indeks modal yang digunakan oleh Boedi (2008) yakni terdiri atas 58 item yang terbagi atas 10 kategori: Merk (5 item), Kompetensi (11 item), Budaya (4 item), Konsumen (8 item), Teknologi Informasi (7 item), Intellectual Property (7 item), Partnership (2 item), Personil (7 item), Proses kepemilikan (6 item), dan Resource \& Development (1 item).

\subsection{Tujuan pengungkapan modal intelektual}

Pengungkapan modal intelektual di dalam laporan tahunan memiliki beberapa kegunaan bagi perusahaan untuk melakukan penilaian kinerja perusahaan dalam memformulasikan strategi, membantu pengambilan sebuah keputusan ekspansi dan diversifikasi, dan dapat digunakan sebagai dasar kompensasi bagi eksternal stakeholders. Sehingga dengan melakukan pengungkapan modal intelektual mampu meningkatkan nilai relevansi laporan keuangan tahunan pada perusahaan tersebut dan pengungkapan modal intelektual dapat mengurangi ketidakpastian dari keseluruhan kondisi perusahaan.

Tujuan pengukuran dan pengungkapan dapat dikelompokkan menjadi 2 bagian yang pertama terkait aktivitas internal perusahaan dan eksternal perusahaan. kegunaan internal perusahaan yakni perusahaan mendapatkan keuntungan dari meningkatnya efesiensi operasional, motivasi dan moral pegawai serta alokasi sumber daya perusahaan yang lebih optimal. Sedangkan untuk kegunaan eksternal perusahaan adalah menjadilkan yang tadinya tidak terlihat menjadi terlihat atau sering disebut juga dengan "render the invisible visible" (Hernita, 2012).

\section{Tingkat Utang}

Definisi tingkat utang menurut Munawir (2012 : 18) adalah seluruh kewajiban perusahaan kepada pihak lain, dimana utang merupakan sumber dan atau modal 
Zamrud Mirah Delima, Zuliyati | Determinan Pengungkapan Modal Intelektual ...

perusahaan yang berasal dari kreditor. Dasar pengukuran utang adalah dengan jumlah rupiah sebagai sumber ekonomi yang harus dikorbankan apabila saat penilaian atau pelaporan utang dapat dilunasi.

Tingkat utang dihitung dengan debt to equity ratio menjelaskan proporsi total utang dibagi dengan ekuitas pemegang saham. Rasio ini digunakan perusahaan untuk mengukur seberapa besar perusahaan bergantung pihak kreditur dalam membiayai ativitas operasional perusahaan. Apabila semakin tinggi tingkat utang suatu perusahaan menunjukkan modal perusahaan tersebut dibiayai oleh utang yang mendominasi. Sehingga terkadang kreditur dapat menuntut aset perusahaan meningkat dan tumbuh berkembang menjadi perusahaan go public.

\section{Pertumbuhan Laba}

Pertumbuhan laba dapat dikatakan menjadi indikator yang sangat vital dalam menilai sebuah kinerja manajemen dan operasional perusahaan yang dapat dihitung dengan cara pendapatan-pendapatan perusahaan dikurangi dengan beban-beban oprasional perusahaan tersebut. Kemudian dikurangkan dengan beban perpajakan sehingga dapat diperoleh nilai laba bersih (net profit) perusahaan. Semakin tinggi laba yang dihasilkan maka semakin sehat pula kondisi sebuah perusahaan tersebut. Hal inilah yang akan menarik minat investor untuk menginvestasikan uang ke perusahaan tersebut. Sebaliknya apabila laba yang dihasilkan perusahaan tersebut turun maka investor tidak tertarik untuk berinvestasi di perusahaan tersebut.

Parameter penilaian kinerja perusahaan yakni terletak pada pertumbuhan laba. Dimana rasio ini menggambarkan tingkat pertumbuhan laba disetiap tahunnya. Pertumbuhan laba sebuah perusahaan menunjukkan kemampuan perusahaan dalam eksistensi perkembangan ekonomi usahanya (Priyanti, 2015). Pengungkapan yang berkualitas akan meningkatkan informasi tentang pertumbuhan laba di masa depan demi menjaga keberlanjutan perusahaan tersebut.

\section{Ukuran Perusahaan}

Ukuran perusahaan merupakan besar kecilnya suatu perusahaan yang dapat diukur dari besarnya total aset yang dimiliki perusahaan. Sehingga ukuran perusahaan menunjukkan kondisi atau karakteristik perusahaan dalam merekrut seberapa banyak karyawan yang akan ditampung, jumlah aktiva, total penjualan, serta jumlah saham yang akan beredar. Ukuran perusahaan merupakan variable penting dalam menjelaskan pengungkapan informasi guna memperoleh dana dan mendapat tekanan dari stakeholders untuk melakukan pengungkapan lebih banyak (Purnomosidhi, 2006).

Menurut Lina (2013) cara menentukan ukuran perusahaan adalah dengan melihat total aset, nialai penjualan, atau nilai kapitalisasi pasar. Setiap perusahaan memiliki karakteristik ukuran perusahaan yang berbeda-beda sehingga memiliki tingkat pengungkapan modal intelektual tersendiri jika diklasifikasikan dari segi ukuran perusaahan kecil dan besar. Perusahaan besar didukung dengan sumber daya yang memadai dalam mengungkapkan lebih banyak informasi serta memiliki manajemen sistem informasi internal yang lebih baik (Andika, 2014).

Jurnal REKSA: Rekayasa Keuangan, Syariah, dan Audit, Vol. 07, No. 02, 2020, pp 133-150 | 137 
Zamrud Mirah Delima, Zuliyati | Determinan Pengungkapan Modal Intelektual ...

\section{Ukuran Dewan Komisaris}

Dewan komisaris dapat dijadikan sebagai alat pengendalian internal sebuah perusahan dalam memastikan tindakan manajer perusahaan atau dewan direksi dalam menjalankan tugasnya telah sesuai dengan keinginan pemilik perusahaan. menurut Haji dan Ghazali (2013) bahwa ukuran dewan komisaris yang lebih besar mampu meningkatkan pengawasan dalam organisasi perusahaan. Selain itu, pihak dewan komisaris memiliki fungsi pengendalian yang mampu menyelaraskan perbedaan kepentingan antara pihak agen dengan prinsipal dalam melaksanakan pengungkapan modal intelektual.

\section{Umur Perusahaan}

Umur perusahaan adalah tahun pertama kalinya perusahaan tersebut didirikan hingga mampu bertahan dan berkembang serta telah tercatat dengan membuktikan akta pendirian sebuah perusahaan tersebut. Menurut Andari (2015) semakin lama perusahaan tersebut berdiri dimana banyak lika-liku yang telah dilalui dalam berbisnis dari kemajuan hingga masalah dan kendala dihadapi. Perusahaan yang telah berumur lebih lama memiliki pengalaman lebih banyak dalam hal publikasi laporan keuangan tahunan perusahaan tersebut. Selain itu, semakin bertambah tahun umur perusahaan akan bertambah pula jumlah aset perusahaan, perusahaan menjadi go public dan investor akan meningkat.

\section{Kompleksitas Bisnis}

Kompleksitas organisasi merupakan akibat dari pembentukan departemen dan pembagian pekerjaan yang mimiliki fokus terhadap jumlah unit yang berbeda (Aryani dan Budiartha, 2014). Kompleksitas bisnis adalah perluasan dari sebuah perusahaan yang memiliki beberapa anak cabang perushaan. Indikator yang mempengaruhi kompleksitas bisnis adalah risiko likuiditas dan risiko operasional. Pengertian risiko likuiditas adalah risiko yang timbul akibat ketidakmampuan bank dalam memenuhi kewajiban yang jatuh tempo. Sedangkan risiko operasional adalah ketidakcukupan dan tidak berfungsinya proses internal yang berakibat terjadinya kesalahan pada manusia dan mempengaruhi operasional bank. Hal inilah yang membuat perusahaan tidak mampu melakukan pengungkapan modal intelektual.

\section{Hubungan determinan pengungkapan modal intelektual pada perusahaan perbankan}

Pengungkapan modal intelektual pada perusahaan perbankan merupakan parameter tingkat pengukuran pencapaian kinerja perusahaan yang akan menjadikan karakteristik tersendiri dalam mempertahankan eksistensi perusahaan sehingga perusahaan tersebut dapat menjadi perusahaan perbankan yang berkualitas dan dapat bersaing di era globalisasi. Modal intelektual diakui dapat meningkatkan keuntungan perusahaan yang labanya dipengaruhi inovasi dan knowledge-intensive service (Cahya, 2013). Beberapa hal yang perlu dilakukan oleh perusahaan perbankan misalnya adalah dengan memberikan pelatihan dan pendidikan sebagai upaya mengembangkan sumber daya manusia

Jurnal REKSA: Rekayasa Keuangan, Syariah, dan Audit, Vol. 07, No. 02, 2020, pp 133-150 | 138 
Zamrud Mirah Delima, Zuliyati | Determinan Pengungkapan Modal Intelektual ...

perusahaan yang dimiliki. Pengungkapan modal intelektual tidak hanya terbatas pada hak paten, hak cipta, dan bentuk-bentuk lain dari kekayaan intelektual, Melainkan merupakan sinergi dari pengetahuan perusahaan, pengalaman, hubungan, proses, penemuan, inovasi, keberadaan pasar dan pengaruh masyarakat (Zuliyati dan Delima, 2017).

\section{Kerangka pemikiran}

Modal intelektual merupakan bentuk pelaporan informasi aktivitas perusahaan dalam mengelola pengetahuan dan sumber daya yang dimiliki. Pelaporan ini dapat menjadi parameter dalam pencapaian kinerja perusahaan, sehingga berkontribusi signifikan dalam meningkatkan persaingan bisnis perbankan. Pengungkapan informasi modal intelektual mampu mengurangi ketidakpastian dari kondisi perusahaan secara menyeluruh sehingga dengan pengungkapan informasi modal intelektual, asimetri informasi, antara pihak manajer dengan investor akan berkurang serta investor lebih yakin akan kondisi kinerja perusahaan untuk dapat mengambil keputusan yang akurat (Hernita, 2012).

Penelitian ini mengusulkan kerangka pemikiran yang menghubungkan pengungkapan modal intelektual pada perusahaan perbankan yang diproksikan dengan tingkat utang, pertumbuhan laba, ukuran perusahaan, ukuran dewan komisaris, umur perusahaan, dan kompleksitas bisnis terhadap pengungkapan modal intelektual. Pengungkapan modal intelektual perbankan dapat menjadi parameter bagi pihak internal dan eksternal perusahaan dalam mengambil sebuah keputusan kebijakan perusahaan dalam meningkatkan daya saing, penilaian perusahaan yang baik dimata pihak eksternal, dan dapat menarik banyak minat investor menanamkan modalnya di perusahaan hingga perusahaan perbankan memiliki peluang berkembang pesat serta mampu bersaing di pasar global. Berikut ini merupakan gambar model kerangka pemikiran penelitian ini :

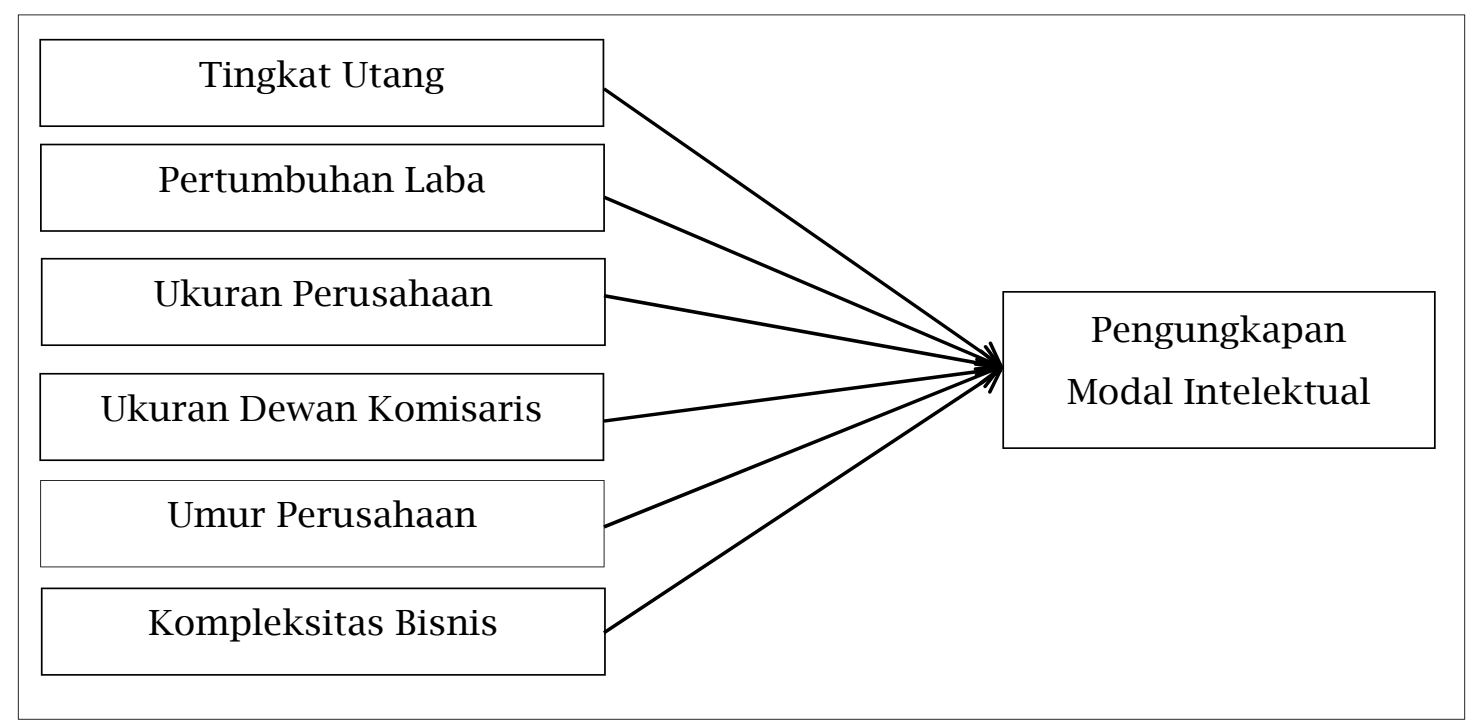

Gambar 10.1. Kerangka Pemikiran

Sumber: Priyanti (2015) yang telah dimodifikasi 
Zamrud Mirah Delima, Zuliyati | Determinan Pengungkapan Modal Intelektual ...

\section{METODE PENELITIAN}

Populasi pada penelitian ini adalah perusahaan perbankan yang terdaftar di Bursa Efek Indonesia ( BEI) dan menyampaikan laporan tahunan secara berturut-turut dari periode 2013 sampai 2019. Teknik pengambilan sampel pada penelitian ini adalah dengan menggunakan metode purposive sampling. Dengan kriteria sebagai berikut : Perusahaan perbankan yang terdaftar di Bursa Efek Indonesia (BEI) tahun 2013 sampai 2019, Perusahaan perbankan yang mempublikasikan laporan keuangan secara lengkap di Bursa Efek Indonesia (BEI) tahun 2013 sampai 2019, Perusahaan perbankan yang menerbitkan laporan keuangan dalam mata uang rupiah, dan tidak termasuk dalam perbankan asing. Sehingga diperoleh sampel sebanyak 175 perusahaan perbankan.

Metode yang digunakan dalam pengumpulan data pada penelitian ini adalah data sekunder. Data-data diperoleh dari laporan keuangan dan annual report yang terdaftar di Bursa Efek Indonesia (BEI) tahun 2013-2019 dengan cara dokumentasi data dari Bursa Efek Indonesia (BEI) atau dengan mengakses situs resmi Bursa Efek Indonesia yaitu : www.idx.co.id.

Indikator yang digunakan dalam pengungkapan modal intelektual adalah terdiri atas 58 item yang terbagi atas 10 kategori : Merk (5 item), Kompetensi (11 item), Budaya (4 item), Konsumen (8 item), Teknologi Informasi (7 item), Intellectual Property (7 item), Partnership (2 item), Personil (7 item), Proses kepemilikan (6 item), dan Resource \& Development (1 item) berdasarkan pada penelitian Boedi (2008). Uji instrumen yang digunakan adalah uji asumsi klasik dan alat pengujian yang digunakan adalah regresi linear berganda.

\section{HASIL DAN PEMBAHASAN}

\section{Statistik Deskriptif}

Analisis desktiptif bertujuan memberikan gambaran atau deskripsi data pada variabel seperti mean, nilai minimum, nilai maxsimum dan standart deviation. Berikut ini merupakan pengolahan data deskriptif :

Tabel. 1.1. Hasil Statistik Deskriptif

\begin{tabular}{lrrrrr}
\hline & N & Minimun & Maximun & \multicolumn{1}{c}{ Mean } & $\begin{array}{c}\text { Std. } \\
\text { Deviation }\end{array}$ \\
\hline Tingkat Utang & 175 & 2,446 & 18,200 & 6,90210 & 2,669236 \\
Pertumbuhan Laba & 175 & $-69,640$ & 49,926 &, 41723 & 7,478497 \\
Ukuran Perusahaan & 175 & 15,097 & 21,072 & $1,79972 \mathrm{E} 1$ & 1,631299 \\
Ukuran Dewan Komisaris & 175 & 2,000 & 9,000 & 5,44571 & 1,925680 \\
Umur Perusahaan & 175 & 15,000 & 106,000 & $4,84400 \mathrm{E} 1$ & 19,271968 \\
Kompleksitas Bisnis & 175 &, 000 & 11,000 & 1,81143 & 2,696078 \\
Pengungkapan Modal & 175 &, 276 &, 621 &, 49868 &, 072798 \\
Intelektual & & & & & \\
Valid N (listwise) & 175 & & & & \\
\hline
\end{tabular}

Sumber: Data Sekunder yang diolah, 2020.

Jurnal REKSA: Rekayasa Keuangan, Syariah, dan Audit, Vol. 07, No. 02, 2020, pp 133-150 | 140 
Zamrud Mirah Delima, Zuliyati | Determinan Pengungkapan Modal Intelektual ...

Dari tabel di atas dapat diketahui bahwa variabel tingkat utang memiliki nilai minimun 2,446 dengan nilai maksimum 18,200. Nilai rata-rata tingkat utang sebesar 6,902 dengan standar deviasi 2,669. Variabel pertumbuhan laba memiliki nilai minimum -69,640 dengan nilai maksimum 49,926. Nilai rata-rata pertumbuhan laba sebesar 0,417 dengan nilai standar deviasi 7,478. Variabel ukuran perusahaan memiliki nilai minimum 15,097 dengan nilai maksimum 21,072. Nilai rata-rata ukuran perusahaan sebesar 1,799 dengan nilai standar deviasi 1,631. Variabel ukuran dewan komisaris memiliki nilai minimum 2,000 dengan nilai maksimum 9,000. Nilai rata-rata ukuran dewan komisaris 5,445 dengan nilai standar deviasi 1,925. Variabel umur perusahaan memiliki nilai minimum 15,000 dengan nilai maksimum 106,000. Nilai rata-rata umur perusahaan 4,844 dengan nilai standar deviasi 19,271. Variabel kompleksitas bisnis memiliki nilai minimum 0,000 dengan nilai maksimum 11,000 dan nilai rata-rata kompleksitas bisnis 1,811 dengan nilai standar deviasi 2,696. Variabel pengungkapan modal intelektual memiliki nilai minimum 0,276 dengan nilai maksimum 0,621 dan nilai rata-rata pengungkapan modal intelektual 0,498 dengan nilai standar deviasi 0,072.

\section{Uji Asumsi Klasik}

\subsection{Uji Normalitas}

Pengujian normalitas dilakuakan dengan menggunakan uji One Sample Kolmogorov Smirnov. Apabila nilai sig $>0,05$ maka data dapat dikatakan terdistribusi normal. Berikut ini merupakan uji normalitas :

Tabel 2.1. Hasil Uji Normalitas

\begin{tabular}{llr}
\hline & & \multicolumn{2}{c}{ Unstandardized Residual } \\
\hline $\mathrm{N}$ & & 175 \\
Normal Parameters $^{\mathrm{a}}$ & Mean &, 0040457 \\
& Std. Deviation &, 21346476 \\
Most Extreme Differences & Absolute &, 098 \\
& Positive &, 079 \\
& Negative &,- 098 \\
Kolmogorov-Smirnov Z & & 1,293 \\
Asymp. Sig. (2-tailed) & &, 071 \\
\hline
\end{tabular}

Sumber : Data Sekunder yang diolah, 2020.

Hasil pengujian normalitas menunjukkan bahwa nilai Asymp. Sig, (2-tailed) sebesar 0,071 yang lebih besar dari 0,05 sehingga data residual dapat dikatakan terdistribusi normal. 
Zamrud Mirah Delima, Zuliyati | Determinan Pengungkapan Modal Intelektual ...

\subsection{Uji Autokorelasi}

Pengujian autokorelasi dilakukan dengan uji run test untuk mengetahui apakah antar residul terdapat korelasi yang tinggi. Berikut ini merupakan pengujian autokorelasi dengan menggunakan run test:

Tabel 2.2. Hasil Uji Autokorelasi

Unstandardized Residual

Test Value ${ }^{\mathrm{a}}$ $-, 00570$

Cases $<$ Test Value 87

Cases $>=$ Test Value 88

Total Cases 175

Number of Runs 82

Z

Asymp. Sig. (2-tailed)

,325

Sumber: Data Sekunder yang diolah, 2020.

\subsection{Uji Multikolonieritas}

Uji multikolonieritas digunakan untuk mendeteksi ada tidaknya gejala multikolonieritas pada data penelitian. Jika nilai VIF tidak lebih dari 10 dan nialai tolerance tidak kurang dari 0,1 maka data dapat dikatakan terbebas dari gejala multikolonieritas. Berikut ini merupakan hasil pengujian multikolonieritas:

Tabel 2.3. Hasil Uji Multikolonieritas

\begin{tabular}{lrrrrr}
\hline \multicolumn{1}{c}{ Model } & \multicolumn{3}{c}{ Correlation } & \multicolumn{3}{c}{ Collinearity Statistics } \\
& Zero-order & Partial & Part & Tolerance & VIF \\
\hline Tingkat Utang &, 117 &, 162 &, 121 &, 971 & 1,030 \\
Pertumbuhan Laba &,- 107 &,- 162 &,- 121 &, 983 & 1,017 \\
Ukuran Perusahaan &, 602 &, 383 &, 306 &, 424 & 2,361 \\
Ukuran Dewan Komisaris &, 404 &, 167 &, 125 &, 679 & 1,472 \\
Umur Perusahaan &, 047 &,- 154 &,- 115 &, 756 & 1,322 \\
Kompleksitas Bisnis &, 500 &, 169 &, 127 &, 550 & 1,818 \\
\hline
\end{tabular}

Sumber: Hasil SPSS yang diolah, 2020. 
Zamrud Mirah Delima, Zuliyati | Determinan Pengungkapan Modal Intelektual ...

Dari hasil penelitian diatas menunjukkan bahwa nilai tolerance disemua variabel lebih dari 0,1 dan nilai Variance Inflation Factor (VIF) juga menunjukkan kurang dari 10. Sehingga dapat disimpulkan bahwa data penelitian tidak terjadi gejala multikolonieritas.

\subsection{Uji Heteroskedastisitas}

Uji heteroskedastisitas digunakan untuk menguji apakah model regresi terjadi ketidaksamaan variance dari residual satu pengamatan ke pengamatan lainnya. Berikut ini merupakan hasil uji heteroskedastisitas :

Tabel 2.3. Hasil Uji Heteroskedastisitas

\begin{tabular}{|c|c|c|c|c|c|}
\hline \multirow[b]{2}{*}{ Model } & \multicolumn{2}{|c|}{$\begin{array}{l}\text { Unstandardized } \\
\text { Coefficients }\end{array}$} & \multirow{2}{*}{$\begin{array}{c}\text { Standardized } \\
\text { Coefficients } \\
\text { Beta }\end{array}$} & \multirow[b]{2}{*}{$\mathrm{t}$} & \multirow[b]{2}{*}{ Sig. } \\
\hline & B & Std. Error & & & \\
\hline (Constant) & ,061 & ,156 & & ,390 & ,697 \\
\hline Tingkat Utang & ,003 & ,004 & 071 & ,931 & ,353 \\
\hline Pertumbuhan Laba & ,001 & ,002 & ,045 &, 596 &, 552 \\
\hline Ukuran Perusahaan & ,002 & ,010 & 025 & ,214 & 831 \\
\hline Ukuran Dewan Komisaris & ,003 & ,006 & 040 & ,434 & ,665 \\
\hline Umur Perusahaan & 000 & 001 & ,018 & ,211 & ,833 \\
\hline Kompleksitas Bisnis & ,008 & ,005 &,- 166 & 1,630 & ,105 \\
\hline
\end{tabular}

Sumber: Data Sekunder yang diolah, 2020.

Dari hasil pengolahan data di atas dapat disimpulkan bahwa seluruh nilai Sig. variabel lebih dari 0,05 jadi dapat disimpulkan tidak terjadi atau bebas gejala heteroskedastisitas.

\subsection{Analisis Regresi linear berganda}

Pengujian analisis regresi linear berganda digunakan untuk menguji pengaruh variabel independen secara bersama-sama terhadap variabel dependen dan pengaruh antara variabel independen dengan variabel dependen. Berikut ini merupakan hasil dari analisis regresi linear berganda : 
Zamrud Mirah Delima, Zuliyati | Determinan Pengungkapan Modal Intelektual ...

Tabel 2.5. Hasil Analisis Regresi Linear Berganda

Model

Unstandardized Coefficients

B

(Constant)

Tingkat Utang

Pertumbuhan Laba

Ukuran Perusahaan

Ukuran Dewan Komisaris

Umur Perusahaan

Kompleksitas Bisnis

, 084
, 003
,- 001
, 021
, 006
, 000
, 004

Std. Error ,062

, 001

, 001

, 004

,003

, 000

,002
Standardized

Coefficients

Beta

Persamaan regresi dalam penelitian ini adalah sebagai berikut :

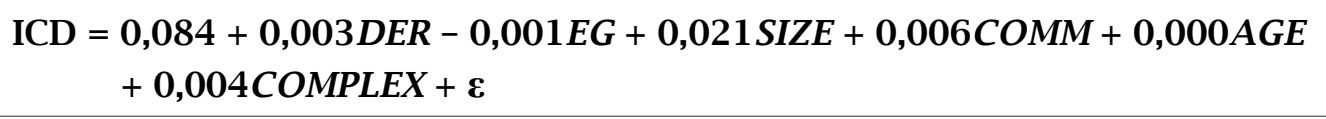

Keterangan:

$\begin{array}{ll}\text { ICD } & =\text { Intellectual Capital Disclosure } \\ \alpha & =\text { Konstanta } \\ \text { DER } & =\text { Debt to Equity Ratio } \\ \text { EG } & =\text { Earning Growth } \\ \text { SIZE } & =\text { Ukuran Perusahaan } \\ \text { COMM } & =\text { Commissioner } \\ \text { AGE } & =\text { Umur Perusahaan } \\ \text { COMPLEX } & =\text { Kompleksitas Bisnis } \\ \varepsilon & =\text { Disturbance Errors }\end{array}$

\section{Goodness Of Fit Model}

\subsection{Koefesien Determinasi}

Koefisien determinasi $\left(\mathrm{R}^{2}\right)$ digunakan untuk mengukur seberapa jauh kemampuan model dalam menjelaskan variasi variabel dependen. Nilai $\mathrm{R}^{2}$ yang kecil berarti kemampuan variabel independen dalam menjelaskan variasi variabel dependen sangatlah terbatas. Berikut ini merupakan hasil pengujian data koefesien determinasi : 
Zamrud Mirah Delima, Zuliyati | Determinan Pengungkapan Modal Intelektual ...

Tabel 3.1. Hasil Uji Koefesien Determinasi

\begin{tabular}{ccccc}
\hline Model & $\mathrm{R}$ & R Square & $\begin{array}{c}\text { Adjusted } \mathrm{R} \\
\text { Square }\end{array}$ & $\begin{array}{c}\text { Std. Error of } \\
\text { The Estimate }\end{array}$ \\
\hline 1 &, $672^{\mathrm{a}}$ &, 452 &, 432 &, 054845 \\
\hline
\end{tabular}

Sumber : Data Sekunder yang diolah, 2020.

Berdasarkan hasil pengolahan data di atas diperoleh nilai adjusted $\mathrm{R}^{2} 0,432$ sehingga dapat diartikan variabel tingkat utang, pertumbuhan laba, ukuran perusahaan, ukuran dewan komisaris, umur perusahaan, dan kompleksitas bisnis memberikan kontribusi 43,2\% terhadap pengungkapan modal intelektual sedangkan sisanya yang sebesar 56,8\% dipengaruhi faktor lain atau variabel lain. Kemudian terdapat hubungan antara variabel tingkat utang, pertumbuhan laba, ukuran perusahaan, ukuran dewan komisaris, umur perusahaan, kompleksitas bisnis, dan pengungkapan modal intelektual yaitu dilihat dari nilai R sebesar $67,2 \%$.

\subsection{Uji F}

Pengujian ini digunakan untuk menunjukkan apakah variabel independen yang dimasukkan dalam model mempunyai pengaruh secara bersama-sama terhadap variabel dependen. Berikut ini adalah hasil dari uji F :

Tabel. 3.2. Hasil Uji F

\begin{tabular}{lrrrrr}
\hline \multicolumn{1}{c}{ Model } & Sum of Square & df & Mean Square & \multicolumn{1}{c}{ F } & \multicolumn{1}{c}{ Sig. } \\
\hline Regression &, 417 & 6 &, 069 & 23,094 &, $000^{\mathrm{a}}$ \\
Residual &, 505 & 168 &, 003 & & \\
Total &, 922 & 174 & & & \\
\hline
\end{tabular}

Sumber: Data Sekunder yang diolah, 2020.

Pada tabel diatas diperoleh nilai $\mathrm{F}=1,541$ dan nilai Sig. $0,000<0,05$. Sehingga dapat dikatakan model penelitian ada pengaruh yang signifikan antara variabel tingkat utang, pertumbuhan laba, ukuran perusahaan, ukuran dewan komisaris, umur perusahaan, dan kompleksitas bisnis terhadap pengungkapan modal intelektual.

\subsection{Uji t}

Uji t memiliki tujuan seberapa jauh pengaruh satu variabel independen dalam menerangkan variabel dependen. Tingkat signifikansi yang digunakan dalam penelitian ini adalah sebesar 0,05. Berikut ini adalah hasil pengolahan uji t : 
Zamrud Mirah Delima, Zuliyati | Determinan Pengungkapan Modal Intelektual ...

Tabel 3.3. Hasil Uji t

\begin{tabular}{lcrccc}
\hline \multicolumn{1}{c}{ Model } & Unstandardized & $\begin{array}{c}\text { Standardized } \\
\text { Coefficients }\end{array}$ & \\
& B & Std. Error & Beta & t & Sig. \\
\hline Constant) &, 084 &, 062 & & 1,360 &, 176 \\
Tingkat Utang &, 003 &, 001 &, 123 & 2,125 &, 035 \\
Pertumbuhan Laba &,- 001 &, 001 &, 122 & $-2,123$ &, 035 \\
Ukuran Perusahaan &, 021 &, 004 &, 471 & 5,366 &, 000 \\
Ukuran Dewan Komisaris &, 006 &, 003 &, 152 & 2,191 &, 030 \\
Umur Perusahaan &, 000 &, 000 &, 133 & $-2,020$ &, 045 \\
Kompleksitas Bisnis &, 004 &, 002 &, 171 & 2,223 &, 028 \\
\hline
\end{tabular}

Sumber: Data Sekunder yang diolah, 2020.

\subsubsection{Pengaruh Tingkat Utang terhadap Pengungkapan Modal Intelektual}

Hipotesis 1: Tingkat Utang berpengaruh signifikan positif terhadap pengungkapan modal intelektual. Hal ini dapat diketahui dari nilai Sig. yang dibawah 0,05 yaitu sebesar 0,035 dan nilai t hitung sebesar 2,125 serta t tabel sebesar 1,97419 dimana t hitung lebih tinggi dari t tabel.

Tingkat utang merupakan perbandingan antara besarnya dana yang disediakan dengan dana yang dipinjami oleh pihak kreditur. Maka tingkat utang yang rendah mengakibatkan pihak internal perusahaan berkeinginan untuk mengungkapkan informasi tentang pengungkapan modal intelektual semakin rendah. Sebaliknya apabila tingkat utang yang tinggi maka pihak perusahaan akan cenderung terbuka terhahap informasi keuangan dan non keuangan.

\subsubsection{Pengaruh Pertumbuhan Laba terhadap Pengungkapan Modal Intelektual}

Hipotesis 2: Pertumbuhan laba memiliki nilai t hitung sebesar -2,123 sementara t tabel sebesar 1,97419 dengan Sig. 0,035. Nilai t hitung lebih rendah dari nilai t tabel sehingga variabel pertumbuhan laba berpengaruh signifikan negatif terhadap pengungkapan modal intelektual.

Pertumbuhan laba merupakan kemampuan perusahaan dalam menghasilkan keuntungan. Pertumbuhan laba perusahaan yang rendah mengakibatkan terjadinya konfilik kepentingan oleh pihak internal untuk berusaha mengurangi informasi yang diberikan terkait kondisi perusahaan yang sedang merugi. Otomatis informasi yang di berikan dalam pengungkapan modal intelektual akan minim. 
Zamrud Mirah Delima, Zuliyati | Determinan Pengungkapan Modal Intelektual ...

\subsubsection{Pengaruh Ukuran Perusahaan terhadap Pengungkapan Modal Intelektual}

Hipotesis 3: Ukuran perusahaan berpengaruh signifikan positif terhadap pengungkapan modal intelektual. Hal ini dapat diketahui dari nilai Sig. yang dibawah 0,05 yaitu sebesar 0,000 dan nilai t hitung sebesar 5,366 serta t tabel 1,97419 dimana $t$ hitung lebih tinggi dari t tabel.

Ukuran perusahaan terbagi atas perusahaan besar dan kecil. Semakin besar ukuran perusahaan maka dalam menyampaikan informasi pengungkapan modal intelektual akan lebih kompleks. Sehingga tuntutan untuk mengungkapkan modal intelektual pada laporan tahunan perusahaan perbankan menjadi tinggi. Dikarenakan pihak eksternal perusahaan terutama investor menuntut keterbukaan informasi perusahaan dalam mengungkap modal intelektual.

\subsubsection{Pengaruh Ukuran Dewan Komisaris terhadap Pengungkapan Modal Intelektual}

Hipotesis 4: Ukuran dewan komisaris berpengaruh signifikan positif terhadap pengungkapan modal intelektual. Hal ini dapat diketahui dari nilai Sig. yang dibawah 0,05 yaitu sebesar 0,030 dan nilai t hitung sebesar 2,191 serta t tabel 1,97419 dimana t hitung lebih tinggi dari t tabel.

Ukuran dewan komisaris menentukan bagaimana sebuah perusahaan dapat mengendalikan sistem pengawasan yang optimal. Dewan komisaris yang berfungsi sebagai pihak pengawas dan pengendali kinerja internal perusahaan menentukan dalam pengungkapan modal intelektual. Akibatnya semakin besar ukuran dewan komisaris maka kinerja pengawasan dan pengendalian menjadi lebih optimal dalam melakukan pengungkapan modal intelektual. Sebaliknya apabila ukuran dewan komisaris kecil maka untuk sistem pengendalian dan pengawasan menjadi kurang optimal sehingga tidak dapat melakukan pengungkapan modal intelektual secara menyeluruh.

\subsubsection{Pengaruh Umur Perusahaan terhadap Pengungkapan Modal Intelektual}

Hipotesis 5: Umur perusahaan memiliki nilai t hitung sebesar -2,020 sementara t tabel sebesar 1,97419 dengan Sig. 0,045. Nilai t hitung lebih rendah dari nilai t tabel sehingga variabel pertumbuhan laba berpengaruh negatif terhadap pengungkapan modal intelektual.

Umur perusahaan yang lebih lama berdiri akan memiliki banyak pengalaman dalam menyajikan laporan tahunan guna menginformasikan tentang pengungkapan modal intelektual secara optimal. Akan tetapi, hal tersebut tidak menjamin perusahaan memiliki kesadaran untuk meningkatkan pengungkapan modal intelektual (Meizaroh dan Lucyanda, 2012). Selain itu, belum ada standar peraturan yang jelas dalam melakukan pengungkapan modal intelektual menjadi salah satu faktor keengganan perusahaan untuk melakukannya.

\subsubsection{Pengaruh Kompleksitas Bisnis terhadap Pengungkapan Modal Intelektual}

Hipotesis 6: kompleksitas bisnis berpengaruh signifikan positif terhadap pengungkapan modal intelektual. Hal ini dapat diketahui dari nilai Sig. yang dibawah 
Zamrud Mirah Delima, Zuliyati | Determinan Pengungkapan Modal Intelektual ...

0,05 yaitu sebesar 0,028 dan nilai t hitung sebesar 2,223 serta t tabel 1,97419 dimana t hitung lebih tinggi dari t tabel.

Kompleksitas bisnis yang besar akan menuntut perusahaan untuk lebih luas menginformasikan pengungkapan modal intelektual. Dikarenakan kompleksitas struktur organisasi perusahaan memiliki beberapa anak cabang sehingga terdapat pendelegasian kewenangan yang berantai sehingga membutuhkan kejelasan transparansi pengelolaan informasi keuangan dan non keuangan. Semakin besar kompleksitas bisnis perusahaan maka pengungkapan modal intelektual akan lebih luas dan menyeluruh.

\section{SIMPULAN, KETERBATASAN DAN SARAN}

Dari hasil penelitian ini maka dapat disimpulkan tingkat utang, ukuran perusahaan, ukuran dewan komisaris, dan kompleksitas bisnis berpengaruh positif signifikan terhadap pengungkapan modal intelektual. Pertumbuhan laba dan umur perusahaan berpengaruh signifikan negatif terhadap pengungkapan modal intelektual. Adapun keterbatasan dalam penelitian ini adalah terdapat enam variabel yang meliputi tingkat utang, pertumbuhan laba, ukuran perusahaan, ukuran dewan komisaris, umur perusahaan, dan kompleksitas bisnis mampu menjelaskan nilai adjusted $\mathrm{R}^{2}$ sebesar $43,2 \%$ sedangkan sisanya $56,8 \%$ dijelaskan oleh variabel lain yang kemungkinan dapat berpengaruh terhadap pengungkapan modal intelektual. Dalam penelitian ini, proksi variabel kompleksitas bisnis hanya dilihat dari jumlah anak perusahaan yang dimiliki oleh perusahaan saja. Atas beberapa keterbatasan tersebut peneliti memberikan saran untuk peneliti selanjutnya menambah variabel bebas lainnya yang belum diteliti dalam penelitian ini. Peneliti selanjutnya disarankan untuk menggunakan proksi level kepemilikan dan proporsi kepemilikan pada kompleksitas bisnis.

\section{DAFTAR PUSTAKA}

Abeysekera, Indra dan J Guthrie. 2005. An Empical Investigation of Annual Reporting Trends of Intellectual Cpital in Sri Lanka. Critical Perspecives on Accounting. Vol. 16. No. 3. Hal 151-163. Australia: University of Wollongong.

Anatan, L. 2006. Manajemen Modal Intelektual: Strategi Memaksimalkan Nilai Intelektual. Technology Driven Business, Vol.5, No. 2. Hal 46-56. Maranatha Christian University.

Andari, Isti Kusuma. 2015. Faktor-Faktor Yang Mempengaruhi Pengungkapan Intellectual Capital. Skripsi. Universitas Muhammadiyah Surakarta.

Andika, Yusfendy Tri. 2014. Faktor-Faktor Yang Mempengaruhi Pengungkapan Modal Intelektual. Skripsi. Universitas Diponegoro: Semarang.

Arifah, Dista Amalia. 2012. Pengaruh Mekanisme Corporate Governance Terhadap Pengungkapan Intellectual Capital Pada: Perusahaan IC Intensive. Jurnal Akuntansi dan Keuangan Indonesia. Vol. 9, No. 2, Desember 2012. Universitas Islam Sultan Agung: Semarang. 
Zamrud Mirah Delima, Zuliyati | Determinan Pengungkapan Modal Intelektual ...

Ariyani, Ni Nyoman T.D \& I Ketut Budhiartha. 2014. Pengaruh Profitabilitas, Ukuran Perusahaan, Kompleksitas Operasi Perusahaan, dan Reputasi KAP terhadap Audit Report Lag pada Perusahaan Manufaktur. Vol. 8. No. 2. Hal 217- 230. Akuntansi Universitas Udayana.

Atmaja, Lukas Setia. 2008. Teori \& Praktik Manajemen Keuangan. Yogyakarta: CV Andi Offset.

Badan Pengawas Pasar Modal dan Lembaga Keuangan. 2006. Keputusan Ketua Badan Pengawas Pasar Modal dan Lembaga Keuangan Nomor kep-134/BL/2006 Tentang Kewajiban Penyampaian Laporan Tahunan Bagi Emiten Atau Perusahaan Publik.

Boedi, Soelistijono. 2008. Pengungkapan Intellectual Capital dan Kapitalisasi Pasar. Tesis. Universitas Diponegoro.

Cahya, Henggar Malika Purna. 2013. Determinan Luas Pengungkapan Modal Intelektual pada Perbankan Tahun 2009-2011. Accounting Analysis Journal, Vol. 2. No. 4. Hal 395-403. Semarang: Universitas Negeri Semarang.

Fitriani, Ayu Erika. 2012. Pengaruh Struktur Corporate Governance Terhadap Pengungkapan Modal Intelektual. Skripsi. Universitas Diponegoro: Semarang.

Ghozali, Imam. 2013. Aplikasi Analisis Multivariate dengan Program IBM SPSS 21. Semarang: Universitas Diponegoro.

Guthrie, J. and Petty, R. (2000), “Intellectual capital: Australian annual reporting practices”, Journal of Intellectual capital, Vol. 1, No. 3, pp. 241-51.

Haji, Abdifatah Ahmed and Nazli A. Mohd Ghazali. 2013. "A Longitudinal Examination of Intellectual Capital Disclosure and Corporate Governance Attributes in Malaysia”, Asian Review of Accounting. Vol. 21. No. 1. Hal 27-52.

Hayton, J.C. (2005), "Competing in the economy: the effect of intellectual capital on corporate entrepreneurship in high-technology new ventures”, R\&D Management, Vol. 35, pp. 137-154.

Hernita, Sri. 2012. Pengaruh Pengungkapan Modal Intelektual Terhadap Biaya Ekuitas dan Biaya Utang. Skripsi. Universitas Indonesia.

Ho, Horace., Kin Chau and Pauline Cheung. 2012. "Intellectual Capital and Initial Public Offerings : Evidence from Hongkong", Journal of Applied Economics and Business Research. Vol. 2. No. 2. Hal 56-68. Hongkong: Hang Seng Management Collage.

Lina. 2013. Faktor-Faktor Penentu Pengungkapan Modal Intelektual. Media Riset Akuntansi. Vol. 3. No. 1. Februari 2013. ISSN: 2088-2106. Tangerang: Universitas Pelita Harapan.

Meizaroh dan Jurica Lucyanda. 2012. Pengaruh Corporate Governance Kinerja Perusahaan dan Umur Perusahaan Terhadap Pengungkapan Modal Intelektual. Media Riset Akuntansi. Vol. 2. No. 1. Hal 65-81. Jakarta: Universitas Bakrie.

Munawir, S. 2012. Analisis Laporan Keuangan. Yogyakarta: Liberty.

Pernyataan Standar Akuntansi Keuangan, 2009. PSAK No. 19 (revisi 2009) Tentang Aset Tidak Berwujud. 
Zamrud Mirah Delima, Zuliyati | Determinan Pengungkapan Modal Intelektual ...

Priyanti, Suci Yuli. 2015. Determinan Pengungkapan Modal Intelektual Berdasarkan Variabel Keuangan dan Non Keuangan. Skripsi. Universitas Negeri Semarang.

Purnomosidhi, Bambang. 2006. Analisis Empiris Terhadap Determinan Praktik Pengungkapan Modal Intelektual pada Perusahaan Publik di BEJ. Universitas Brawijaya.

Subramanyam, K.R., John Wild. 2010. Analisis Laporan Keuangan. Jakarta: Salemba Empat.

Tayles, M., Bramley, A., Adshead, N., and Farr, J. (2002), "Dealing with the management of intellectual capital: The potential role of strategic management accounting", Accounting, Auditing \& Accountibility Journal, Vol. 15, No. 2, pp. 251-67.

Zuliyati Z., Budiman N.A. dan Delima Z.M. Pengaruh Intellectual Capital Terhadap Kinerja UMKM (Studi Kasus Pada UMKM Di Kabupaten Kudus). Jurnal Akuntansi dan Keuangan. Vol. 6. No. 2. Oktober 2017. ISSN: 2252-7141. Universitas Budi Luhur. 